\title{
ON CTENOLUCIUS GILL, A NEGLECTED GENUS OF CHARACIN FISHES, WITH NOTES ON THE TYPICAL SPECIES.
}

\author{
By Barton A. Bean, \\ Assistant Curator, Division of Fishes, U. S. National Museum.
}

In a footnote to his Catalogue of the fishes of the east coast of North America, Greenland to Georgia, inserted at the end of the Proceedings of the Academy of Natural Sciences of Philadelphia, XIII, for 1861 (1862), page 8, Dr. Theodore N. Gill proposed the name Ctenolucius for fishes closely allied to the Xiphostomas of Spix, but having the dorsal fin placed far back, the scales very strongly ctenoid, etc. I quote Doctor Gill's note in full:

In a species preserved in the Musenm of the Smithsonian Institution, nearly allied to the Xiphostomas of Spix, and especially to the Xiphostoma hujeta of Valenciennes, the scales are covered with numerous closely approximated ridges abruptly commencing at the bases of their exposed surfaces and terminating in as many strong teeth on the posterior margin. Valenciennes has not described the structure of the scales in the species of Xiphostoma known to him. But he, as well as Müller and Troschel in the "Horæ Ichthyologicæ," have mentioned them as being of moderate size. The ridges and pectinated margins of those of our fish are so strongly marked that it is scarcely possible that they should have been overlooked if they occurred in the species known to the very excellent naturalists above mentioned.

The dorsal fin of our fish is more posterior than in the typical Xiphostomas, being above the anal; the anus is under the anterior rays of the dorsal. In this respect it resembles Xiphostoma maculatum and $X$. huieta of Valenciennes.

Three specimens of the species were collected at Truando by Mr. Arthur Schott on Lientenant Michler's expedition to the Atrato River. They will be described under the generic name of ctenolucius. It must remain undecided whether the two species of Xiphostoma of Valenciennes, agreeing in the position of the dorsal and anal fins, are really congeneric.

In 1878, in his paper entitled Zur Fisch-Fauna des MagdalenenStromes, Dr. Franz Steindachner described a species of Characin from the Magdalena River under the generic name Luciocharax, with the following characterization: Form of body and snout essentially as in Xiphostoma. Intermaxillary and lower jaw very long, the former beset anteriorly with two rows of larger teeth. The palatine teeth numerous and very small. Dorsal and anal inserted far back- 
ward. Scales of the body considerably larger than in Xiphostoma. Lateral line incompletely developed.

An excellent figure is given by Doctor Steindachner in the paper cited above (Plate XIII, fig. 2), and the species, which is called insculptus, is fully described on pages 51-53. It is very similar to hujeta, differing mainly in the depth of body, and may be identical with that species.

C. maculatus, another species of this group, has 88 scales in the lateral line, being intermediate in this respect between $C$. hujeta and the many-scaled species cuvieri and ocellatum, which have 105 to 106 scales.

The following genera are now included in the subfamily Xiphostomince:

Xiphostoma Spix, Pisces Brasilienses, 1829, pp. 78-79. Type, X. cuvieri.

Ctenolucius Glle, Proc. Acad. Nat. Sci. Phila., 1861, p. 8 of appendix. Type, C. hujeta.

Luciocharax Steindachner (a synonym of Ctenolucius), Zur Fisch-Fauna des Magdalenen-Stromes, 1878, pp. 51-53. Type, L. insculptus.

Boulengerella EIgenManN (similar to or identical with Ctenolucius), Smith. Mis. Col., XLV, 1903, p. 147. Type, Xiphostoma lateristriga Boulenger.

Belonocharax Fowler (a synonym of Ctenolucius), Proc. Acad. Nat. Sci. Phila., LVIII, Pt. 3, Oct., 1906, pp. 464-466. Type, B. beani.

Judging from the illustration of Xiphostoma cuvieri, in Spix's Pisces Brasilienses, Plate XLII, all species coming under the subfamily Xiphostomince probably have pectinate scales. In a recent letter, Dr. C. H. Eigenmann says that there is no doubt that the genera Ctenolucius, Luciocharax, and Belonocharax are identical. He examined the types of hujeta and insculptus while in Europe last summer, and has little doubt that they represent the same species.

The following notes are taken from two specimens of Ctenolucius hujeta preserved in the collections of the U. S. National Museum, being the examples mentioned by Doctor Gill in 1861:

Description.-A male, 9 inches long, Cat. No. 1658, U.S.NM., taken in the Truando River, a tributary of the Atrato River, United States of Colombia, winter of 1857 and 1858, A. Schott, collector: ${ }^{a}$

Head 3 ; depth 7 ; eye 3 in snout, 7 in head; D. 10 ; A. 12 (3,9); V. 1,7 ; scales $49,5 / 1 / 6$.

Body elongate, pike-shaped, entirely covered with strongly pectinate scales; teeth of the jaws in a single series, very regular, pointed and curved backward; a few strong palatine teeth; mandibular barbels present, one on either side near tip of lower jaw; upper jaw strongly curved in anterior part and slightly projecting over the

$a$ Survey for Interoceanic Ship Canal via the Atrato and Truando Rivers, Dec. 1, 1857, to Mar. 23, 1858. Senate Doc. 9, 2 d sess., 36th Cong., VII, Pt. 1, $1860-61$. 
lower jaw, the latter when closed fitting snugly into the upper; head entirely covered with flat, finely sculptured, bony processes; fins all well developed; pectorals rather less than half length of head; dorsal fin situated far back, its origin being but slightly in advance of that of the anal, the extended rays of the latter almost reaching to the caudal fin; caudal deeply emarginate; the anal fin of the male specimen much enlarged; caudal peduncle elongate, its length measured from anal fin to origin of middle caudal rays, being about equal to the length of the snout.

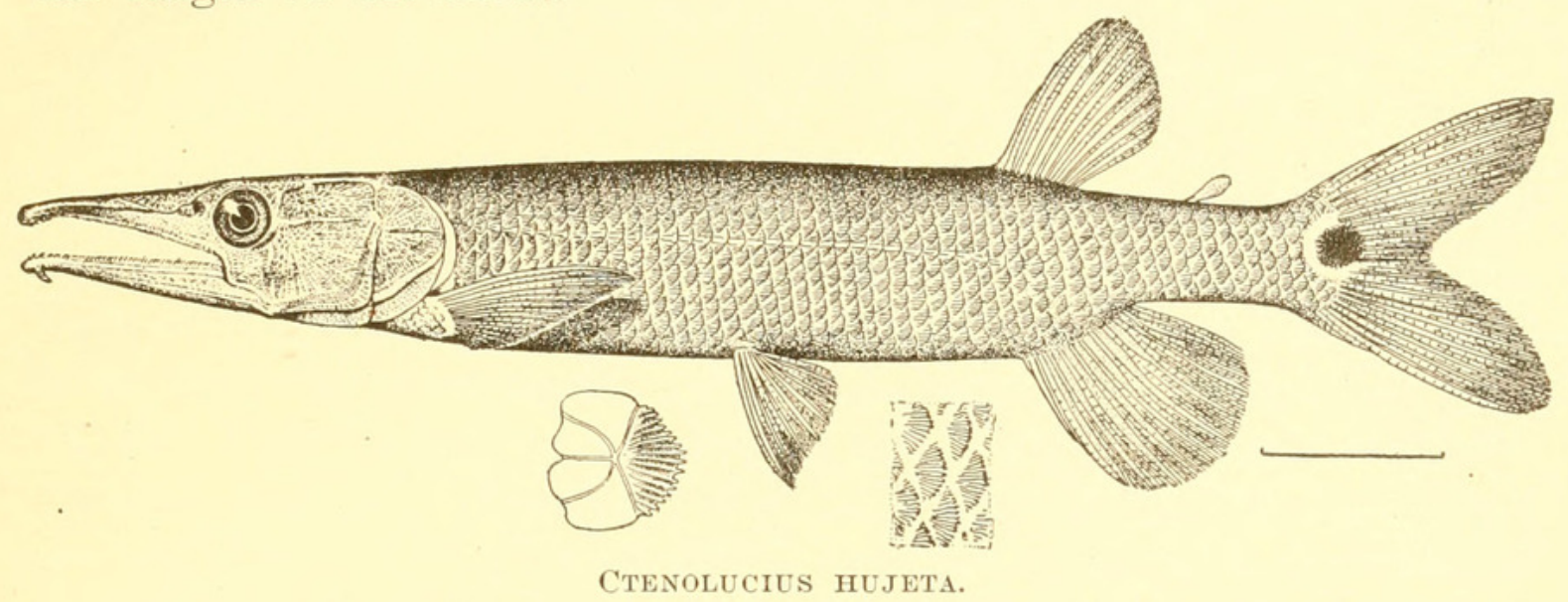

Color in spirits: Upper parts rusty (brownish) with faint horizontal lines extending on the body from head to caudal; lower parts lighter, silvery; opercular flap silvery; eye dark on top, golden around the jet-black iris, pupil a rusty yellow; dorsal, anal, and caudal slightly dusky; pectorals and ventrals plain; the black ocellus at origin of caudal very conspicuous.

Another example, a female 8 inches long, from the same source as the foregoing, has slenderer jaws and a much smaller anal fin. A third example from this lot was sent years ago to the Academy of Natural Sciences of Philadelphia, where it is now preserved.

Proc. N. M. vol. xxxiii- $07-45$ 


\section{$2 \mathrm{BHL}$ Biodiversity Heritage Library}

Bean, Barton A. 1908. "On Ctenolucius Gill, a neglected genus of characin fishes, with notes on the typical species." Proceedings of the United States National Museum 33, 701-703.

View This Item Online: https://www.biodiversitylibrary.org/item/53442

Permalink: https://www.biodiversitylibrary.org/partpdf/51962

\section{Holding Institution}

Smithsonian Libraries

\section{Sponsored by}

Smithsonian

\section{Copyright \& Reuse}

Copyright Status: Public domain. The BHL considers that this work is no longer under copyright protection.

This document was created from content at the Biodiversity Heritage Library, the world's largest open access digital library for biodiversity literature and archives. Visit BHL at https://www.biodiversitylibrary.org. 